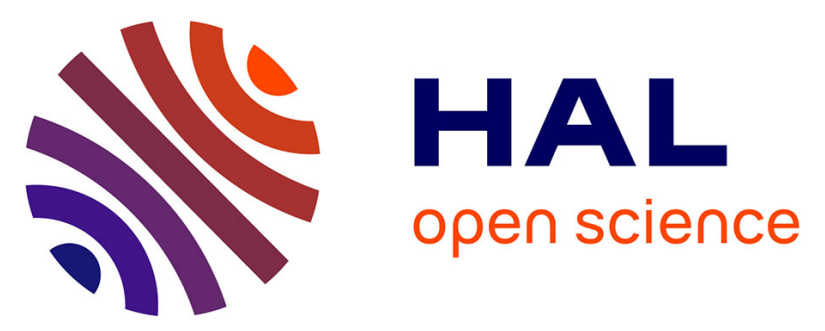

\title{
Ashes in the air: the effects of volcanic ash emissions on plant-pollinator relationships and possible consequences for apiculture
}

Andrés Martínez, Maité Masciocchi, José Villacide, Guillermo Huerta, Luis Daneri, Axel Bruchhausen, Guillermo Rozas, Juan Corley

\section{To cite this version:}

Andrés Martínez, Maité Masciocchi, José Villacide, Guillermo Huerta, Luis Daneri, et al.. Ashes in the air: the effects of volcanic ash emissions on plant-pollinator relationships and possible consequences for apiculture. Apidologie, 2013, 44 (3), pp.268-277. 10.1007/s13592-012-0177-2 . hal-01201295

\section{HAL Id: hal-01201295 \\ https://hal.science/hal-01201295}

Submitted on 17 Sep 2015

HAL is a multi-disciplinary open access archive for the deposit and dissemination of scientific research documents, whether they are published or not. The documents may come from teaching and research institutions in France or abroad, or from public or private research centers.
L'archive ouverte pluridisciplinaire HAL, est destinée au dépôt et à la diffusion de documents scientifiques de niveau recherche, publiés ou non, émanant des établissements d'enseignement et de recherche français ou étrangers, des laboratoires publics ou privés. 


\title{
Ashes in the air: the effects of volcanic ash emissions on plant-pollinator relationships and possible consequences for apiculture
}

\author{
Andrés S. MartíneZ ${ }^{1}$, Maité Masciocchi ${ }^{1}$, José M VILlacide ${ }^{1}$, Guillermo Huerta ${ }^{2}$, \\ Luis DanerI ${ }^{2}$, Axel BruchHausen ${ }^{3}$, Guillermo Rozas ${ }^{3}$, Juan C. Corley ${ }^{1}$ \\ ${ }^{1}$ Grupo de Ecología de Poblaciones de Insectos, INTA EEA Bariloche, San Carlos de Bariloche, Argentina \\ ${ }^{2}$ INTA EEA Bariloche, San Carlos de Bariloche, Argentina \\ ${ }^{3}$ Grupo de Fotónica \& Optoelectrónica, Instituto Balseiro and Centro Atómico Bariloche, San Carlos de Bariloche, \\ Argentina
}

Received 11 July 2012 - Revised 28 September 2012 - Accepted 22 October 2012

\begin{abstract}
Pollinator foraging performance could be altered by volcanic ash contaminated flowers, pollen, and nectar. We used the honeybee (Apis mellifera) as a model organism to understand the effects that volcanic ash could have on apiculture and establish some of the mechanisms through which it could affect plant-pollinator interactions. Three mechanisms were investigated: (1) interference with resource location, (2) interference with resource consumption, and (3) disturbing digestive processes. Results indicate that plant-pollinator relationships could be altered by volcanic ash. On the one hand, honeybees seem to recognize flowers covered in ashes only after an adaptation period (i.e., learning). On the other hand, there is no avoidance mechanism to prevent ingestion of contaminated food that ultimately reduces survival. Apiculture could be negatively affected due to this natural disturbance and plant-pollinating relationships could be especially vulnerable to ash emissions due to the high exposure of pollen and nectar bearing structures susceptible to contamination. Additionally, nectar feeders gut morphology (i.e., convoluted, thin with no resistance to abrasion) enables ash particles in contaminated food to obstruct and lacerate the gut increasing mortality risk.
\end{abstract}

Apis mellifera / disturbance / pollinator / volcanic ash / volcanic complex Puyehue Cordon Caulle

\section{INTRODUCTION}

Plant-pollinator relationships are thought to be one of the key factors responsible for maintaining community structure in natural ecosystems, with most angiosperms (>80\%) strongly depending on a second organism for reproduction (Ollerton et al. 2011). In addition, pollinators benefit a third of the food

Corresponding author: A.S. Martínez, andresmartinez@bariloche.inta.gov.ar Manuscript editor: David Tarpy we consume with a major part of fruit, vegetable, and seed production worldwide is improved in terms of quantity and/or quality by bees (Hymenotpera: Apiformes) (Klein et al. 2007).

The balance in plant-pollinator relationships is delicate because of the interdependence between both parts. Disruptions on either side could lead to plants not reproducing sexually and animal populations declining due to unavailability of carbohydrates and proteins sources with important ecological and economic consequences. In this sense, the dynamics of 
plant-pollinator relationships are subjected to a broad range of natural and anthropogenic perturbations. It has been reported that disturbances such as fire regimes can modulate assemblage composition through time (Potts et al. 2003), climate change can cause temporal mismatches of mutualistic partners (Hegland et al. 2009), and biological invasions frequently cause profound disruptions to plant reproductive mutualisms (Traveset \& Richardson 2006). Similarly, volcanic eruptions can result in comparatively large areas being affected (Foster et al. 1998). In addition to the regional effects of the direct force of the blast and lava flow, this type of geological activity can affect remote locations. The large quantities of gases emitted to the stratosphere affect solar radiation and can cause shifts in weather and climate (Robock 2000), or the thin portion of airborne material (commonly known as ashes) can be transported by wind currents to remote locations and persist over long periods with adverse effects, even after the end of the volcanic activity (Wilson et al. 2010).

To date, there are a limited number of studies dealing with the way in which volcanic ash can impact the biota. This is surprising because volcanic activity is not as infrequent as intuition would suggest. Simkin (1993) estimated that worldwide, there are between 55 and 70 volcanic eruptions/year with most of them having local to regional impacts. Additionally, despite the risks of living close to volcanoes, $20 \%$ of humans lived within $200 \mathrm{~km}$ of a volcano in 1990 (Small and Naumann 2001). This is linked to the fact that soils from volcanic origin harbor an enormous potential for agricultural production; hence, most of the productive regions in the world have been developed near volcanoes (Shoji et al. 1993) regardless of being under risk of suffering from their (in some cases devastating) effects.

Some of the few studies conducted in this area indicate that volcanic ash can alter arthropod behavior and survival in different ways. For example, ash in the atmosphere can alter honeybee behavioral aspects such as flight patterns (Woyke and Gabka 2011). In cases were survival is decreased, the underlying mechanisms through which this occurs is believed to be based on the hygroscopic and abrasive nature of volcanic particles that affects tissues and vital systems (Klostermeyer et al. 1981) and alters digestive processes and obstructs respiratory systems (Wille and Fuentes 1975, Edwards and Schwartz 1981). Increasing our understanding on the impacts of volcanic eruptions is important if we want to successfully predict and mitigate the consequences of this type of disturbance on key biological interactions and possible knock-on effects on economic activities, especially when considering how little is known about the impacts of one of the most far-reaching effects of volcanic eruptions (i.e., ashes). Pollinator performance is essential since it implies sexual reproduction for the plant and resource availability for the pollinator (Ne'eman et al. 2010). In order to locate nectar and pollen, many pollinators rely on floral visual and chemical cues (Raguso and Willis 2005), and once found, resource quality (and quantity) can determine, between other factors, the frequency of revisits. Under a volcanic disturbance, flower appearance and resource quality could be altered by ash fall and have a direct consequences on the fitness of both parts. We studied the effects of ash released in Patagonia between 2011 and 2012 by the Puyehue-Cordon Caulle volcanic complex on honeybee behavior and survival. We used the honeybee as a model organism to understand some of the possible mechanisms and consequences that volcanic ash fall could have on plant-pollinator interactions and possible knock on effects to apiculture. We focused on three possible ways through which volcanic ash could affect the honeybee: (1) interference with resource location, (2) interference with resource consumption, and (3) by affecting survival through ingestion.

\section{MATERIALS AND METHODS}

\subsection{Volcanic ash}

Ash used in all manipulative experiments was collected from Rincon Chico, Argentina (40 59'29" S- 
$\left.71^{\circ} 06^{\prime} 06^{\prime \prime} \mathrm{W}\right)$, product of the Chilean volcanic complex Puyehue-Cordon Caulle $\left(40^{\circ} 32^{\prime} 25^{\prime \prime}\right.$ S- $\left.72^{\circ} 7^{\prime} 2^{\prime \prime} \mathrm{W}\right)$, which erupted in June 4, 2011 and continued its activity until July 2012. The collected ash was sieved $(<0.05 \mathrm{~mm})$ to obtain a particle size range close to that remobilized by wind (Wilson et al. 2010) and match traces found within nectar foragers crop contents (Martínez, personal observation).

\subsection{Honeybee rearing}

All experiments involved the use of honeybees Apis mellifera (derived from Carnolian). Adults used in manipulative experiments were obtained from brood frames removed from the apiary located at National Institute of Agricultural Technology field facilities in Bariloche, Argentina. Frames were placed in an incubator $\left[35{ }^{\circ} \mathrm{C}, 55 \%\right.$ relative humidity (RH)], and adults were collected daily and placed inside wire-mesh cages $(0.1 \times 0.1 \times 0.1 \mathrm{~m}$, mesh $2 \mathrm{~mm}$ ) in groups of 50 individuals. Three individual feeders were placed at the center of each cage with pollen, water, and sucrose solution $(1.8 \mathrm{M})$. All resources were offered ad libitum. Commercially available multi-floral pollen was mixed with distilled water to create a paste, which was then loaded onto feeders.

\subsection{Experiment 1: flower location behavior}

To test whether volcanic ash deposits on flowers could affect honeybee location behavior, flower visits were measured in the field on flowers contaminated with ash against clean flowers. The study was carried out in an ash-free lavender (Lavandula sp.) plantation $(30 \times 2.5 \mathrm{~m})$ in bloom near an apiary consisting of five colonies (distant $\sim 50 \mathrm{~m}$ ) in the Bariloche region. Four plots $(0.8 \times 0.8 \mathrm{~m})$ were delimited within the plantation with a 2-m gap between each other. An estimation of the rate of visits [individuals (ind)/ $1 \mathrm{~min} / \mathrm{plot}$ ] was obtained at 4-min intervals. Since plots differed in the number of lavender spikes (control $1=199$, control $2=360$, treated with ash $1=$ 215 , treated with ash $2=294$ ), data were standardized by obtaining the quotient between the visit rate and the number of spikes (ind/min/spike). After $1 \mathrm{~h}$ of measurements being started, two plots were dusted with ash to recreate a scenario resulting from heavy ash rain (Martínez, personal observation). In order to do this, $100 \mathrm{~g}$ of ash were placed on a fine-meshed sieve $(0.5 \mathrm{~mm}$ mesh size $)$ and the entire surface of each treated plot was sprinkled with this ash. To prevent any ash from falling on flowers outside the plot, during the sprinkling process, the plot was surrounded by a $0.5-\mathrm{m}$ tall cardboard containment fence. Once the ash was applied, the containment was removed. In this way, every flower within each treated plot was covered by a relatively high and similar amount of volcanic ash. The remaining two plots (control) were left untreated (i.e., ash-free flowers). After ash application, measurements were continued for an additional $3 \mathrm{~h}$. Twenty-four hours since starting the experiment, visit rates were measured for an additional hour. Data was pooled within ashtreated and control plots at time intervals $0-1,1-3$, and 24-25 h. Visit rates between different times within the control plot were compared with an ANOVA. A MannWhitney-Wilcoxon rank sums test was used for comparing visit rates in contaminated plots since data did not fit the normality assumption.

To assess any possible changes in the visual information (i.e., spectral change) that honeybees would perceive, the reflectance of five (1) clean flowers and (2) same flowers covered in ashes (recreating the same contamination level as in field experiment) were quantified by measurements reflectivity. White light from a Xe light bulb was shone on (1) a clean (no ash) lavender flower and (2) a contaminated lavender flower. Part of the light reflected from (1) and (2) was analyzed spectrally using a charged coupled device equipped nearultraviolet-near-infrared spectrometer (Acton Research Corp., model SP-300i). The light was focused onto an area of approximately $1 \mathrm{~mm}^{2}$, and the angle of the collection cone of the measured dispersed light was about $15^{\circ}$. Measurements were standardized vs. light reflected from a highly dispersive and uniform (within the analyzed wavelength range) surface.

\subsection{Experiment 2: resource consumption}

Adult honeybees of known age were obtained following the method described above. They were fed pollen, water and sugar solution ad libitum contaminated with varying concentrations of ash $(0,1 \%$, and $5 \% w / w)$. Twenty-seven treatments (cages) were 
set up, with the resources containing different amounts of ash. Cages were kept in an incubator in the dark at $35{ }^{\circ} \mathrm{C}$ and $55 \% \mathrm{RH}$. A small piece $(3 \times$ $3 \mathrm{~cm})$ of meshed cloth $(2 \mathrm{~mm})$ was placed inside sugar solution and water feeders to prevent ash decantation to the bottom of each device. Dead bees were removed daily. Contaminated food consumption was measured indirectly by quantifying the ingestion of pollen, sugar solution and water. The consumed amount of each resource was established daily gravimetrically by weighing feeders and subtracting the cumulative consumption and dividing by the number of live individuals. Measurements were taken daily until all individuals in the cage were dead. Some measurements had to be discarded due to leaks in feeders. Consumption for each resource/contamination level were averaged and compared with a Kruskal-Wallis test since data did not fit the normality assumption. Because adults only consume pollen within the first 2 weeks of adulthood (Hrassnigg and Crailsheim 1998), and additional comparison of pollen consumption considering this time frame was done.

\subsection{Experiment 3: ingestion of contaminated food}

To evaluate the effect of ingesting contaminated food on survival, additional data was collected from the cages set up in experiment 2. Each of the 27 cages containing honeybees was considered as an experimental unit (i.e., replicate). An approximation to honeybee survival was done by quantifying the "survival" of each cage. A cage was considered as "dead" once all the 50 individuals had died. In order to visualize the results, Kaplan-Meier survival curves were generated considering each contamination level/type of resource by plotting the proportion of "live" cages over time. Differences in survival were analyzed with log-rank tests (Kleinbaum and Klein 2006). A Cox proportional hazards model was carried out to assess two-way interaction effects between resources and to quantify the change in survival risk for the two levels of contaminated food vs. the uncontaminated resource. A risk ratio $>1$ indicates a higher risk of death vs. the control (for example, a risk ratio of 2 is interpreted as twice the probabilities of death compared to the control group).

\section{RESULTS}

\subsection{Experiment 1: flower location behavior}

While visit rates in control treatments throughout the duration of the experiment $(0-1,1-3$, and $2-25 \mathrm{~h})$ were not significantly different (overall mean $=0.052 \mathrm{ind} /$ $\mathrm{min} /$ spike; $F=1.74 ; P>0.05 ; d f=2$ ), after ash application visit rates dropped significantly vs. same flowers with no ash (median $0-1 \mathrm{~h}=0.05$; ind $/ \mathrm{min} / \mathrm{spike;} \mathrm{median} 1-3$ $\mathrm{h}=0.0068 \mathrm{ind} / \mathrm{min} / \mathrm{spike} ; Z=8.33 ; P<$ 0.00001 ) (Figure 1). When $24 \mathrm{~h}$ had elapsed since ash application, visit rates in contaminated flowers increased (median value treated $=0.023 \mathrm{ind} / \mathrm{min} /$ spike $Z=7.64 ; P<$ $0.0001)$ but not to initial uncontaminated levels $(Z=4.00 ; P<0.0001)$.

An overall increase in reflectivity was registered in ash-contaminated vs. clean flowers (Figure 2). The same change was observed across all flowers. Between 350 and $650 \mathrm{~nm}$ the reflectivity increased on average $\sim 10 \%$ with maximum differences found at $\sim 400 \mathrm{~nm} \mathrm{(30 \%}$ increase) and a broader band around $\sim 570 \mathrm{~nm}$ (15\% increase).

\subsection{Experiment 2: resource consumption}

The consumption rates of pollen, sugar solution, and water contaminated with different amounts of volcanic ash were not different from controls (pollen: $N_{0} \%=143, N_{1 \%}=146, N_{5} \%=$ 155 , overall median $=0.91 \mathrm{mg}$ /day KruskalWallis test, $\chi^{2}=1.43, P>0.05, d f=2$; sugar solution: $N_{0} \%=151, N_{1} \%=140, N_{5} \%=127$, overall median $=24.06 \mathrm{mg} /$ day; $\chi^{2}=3.65, P>$ $0.05, d f=2$; water: $N_{0} \%=175, N_{1} \%=118$, $N_{5} \%=101$, overall median $=9.6 \mathrm{mg} / \mathrm{day}, \chi^{2}=$ $2.25, P>0.05, d f=2$ ) (Figure 3). Pollen consumption in the first 15 days of adulthood was not 


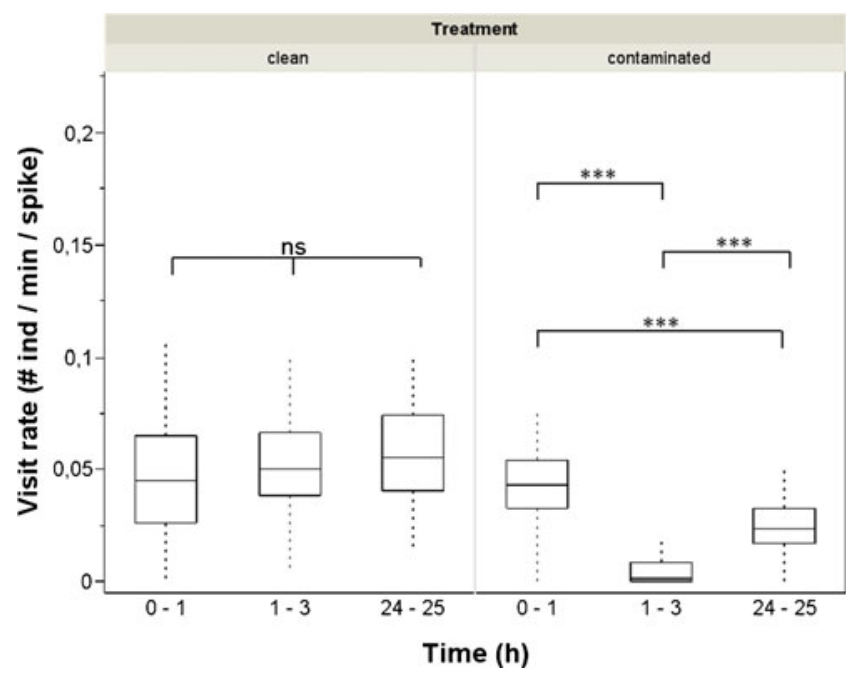

Figure 1. Honeybee visit rates in lavender spikes free of ashes (clean) and treated with ashes (contaminated). Ash was sprinkled $1 \mathrm{~h}$ after the experiment was started. Visits were standardized by the number of lavender spikes present in the plots. After a simulated ash rain, visits to contaminated plots, dropped significantly. Twenty-four hours after ash application, visits increased again, but not to initial levels. The top and bottom of the box indicate the interquartile range. The line across the middle indicates the median value. Vertical dotted lines indicate spread of data.

significantly different between treatments $\left(\chi^{2}=\right.$ 1.87, $P>0.05, d f=2)$. Pollen consumption was significantly lower in comparison to that of sugar solution and water (Wilcoxon test, $\chi_{\text {pollen-sugar }}^{2}$ solution $=242.48, P>0.0001, d f=1 ; \chi_{\text {pollen-water }}^{2}=$ 192.49, $P>0.0001, d f=1)$

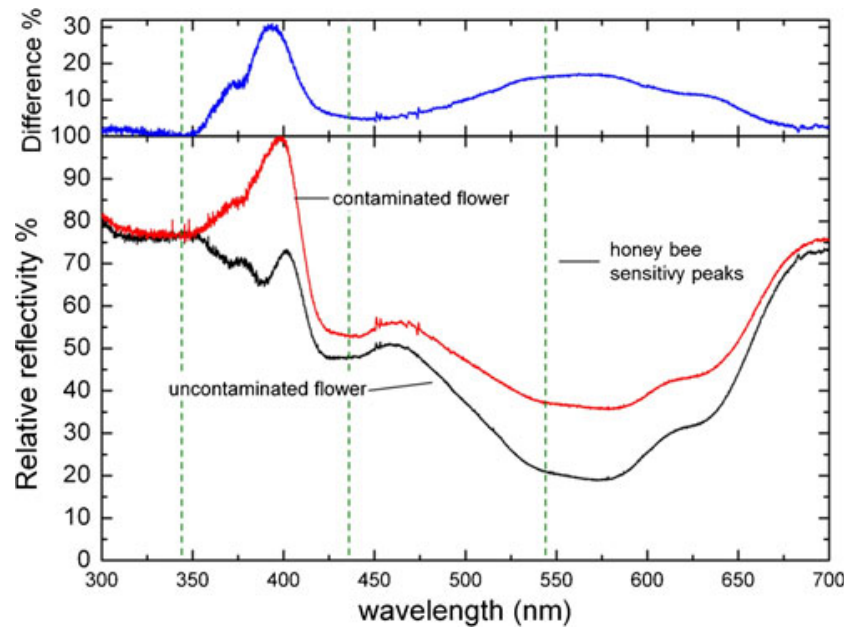

Figure 2. Change in reflectivity of uncontaminated flowers vs. ash-contaminated flowers. Several samples were measured with and without contamination, with equivalent results. In this figure typical results are shown. The largest spectral differences occur mainly around a wavelength of $\sim 400 \mathrm{~nm}$ and a broader band around $\sim 570 \mathrm{~nm}$. Dotted green lines indicate honeybee spectral sensitivity peaks. 


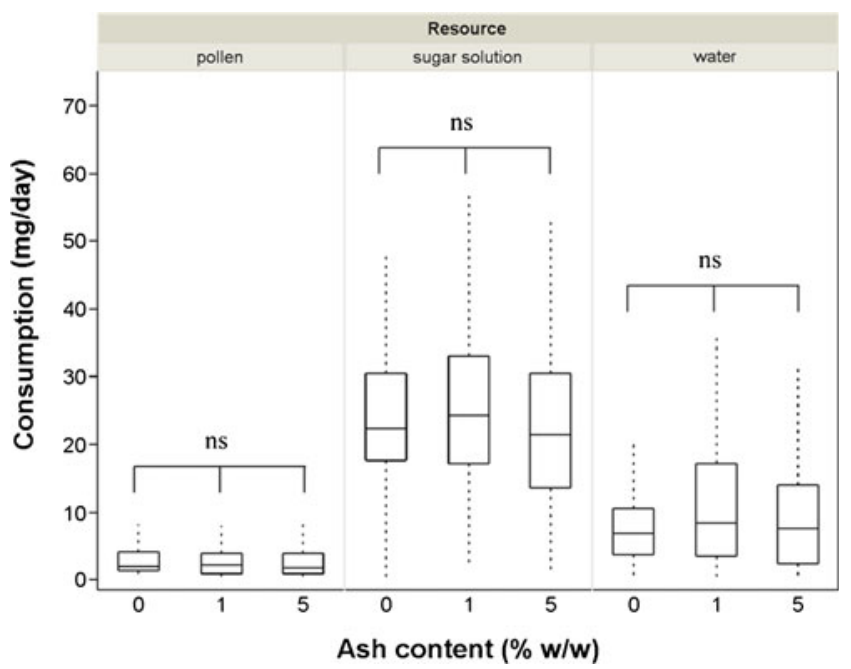

Figure 3. Honeybee consumption rate (mg/day) of pollen, sugar solution, and water contaminated with 1 and $5 \%$ volcanic ash. No significant differences were found in the consumption vs. the control treatment free of ashes. The top and bottom of the box indicate the interquartile range. The line across the middle indicates the median value. Vertical dotted lines indicate spread of data.

\subsection{Experiment 3: food ingestion}

Honeybee survival was affected by the ingestion of contaminated sugar solution and water (Figure 4). A log rank test of the survival curves of each contamination level within each food type vs. their respective control treatments revealed a significant effect at $5 \% w / w$ contamination of sugar solution and water (Table I), while contaminated pollen did not have a significant effect on survival. No interactions were found between resources (pollen $\times$ water $\chi^{2}=0.12, P>0.05$, $d f=1$; pollen $\times$ sugar solution $\chi^{2}=0.37, P>$ $0.05, d f=1$; water $\times$ sugar solution $\chi^{2}=0.13$, $P>0.05, d f=1)$.
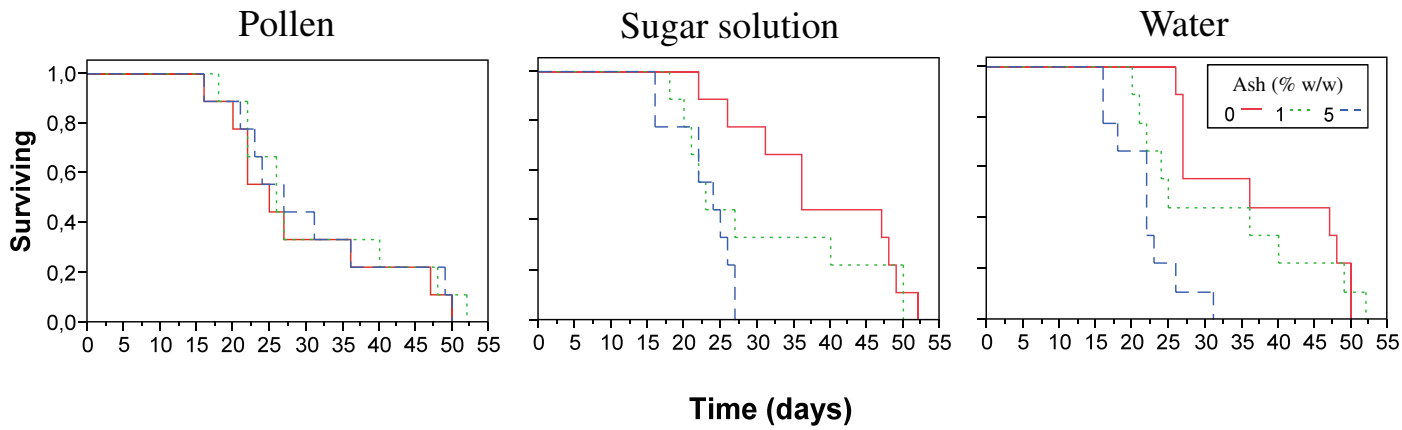

Figure 4. Kaplan-Meyer survival curves showing the proportion honeybees surviving after being fed with water, pollen, and sugar solution contaminated with different degrees $(0,1$, and $5 \% \mathrm{w} / \mathrm{w})$ of ashes. A significant dose-dependent effect was observed for contaminated water and sugar, while eating contaminated pollen did not affect survival. No interaction effects on survival were found among the different types of food. 
Table I. Log-rank tests and Cox's proportional hazards analysis of survival of honeybees fed with contaminated vs. uncontaminated resources (significant negative effects on survival were found for the highest contamination levels of sugar solution and water; risks $>1$ with $P<0.05$ indicate significant reductions in survival).

\begin{tabular}{lllllll}
\hline Resource & Pollen & \multicolumn{3}{l}{ Sugar solution } & \multicolumn{3}{l}{ Water } \\
\hline$\%$ Ash $(w / w)$ & 1 & 5 & 1 & 5 & 1 & 5 \\
Log rank test $\left(\chi^{2}\right)$ & 0.35 & 0.07 & 0.84 & 11.13 & 0.48 & 12.81 \\
$d f$ & 1 & 1 & 1 & 1 & 1 & 1 \\
$P$ value & 0.55 & 0.79 & 0.36 & 0.0009 & 0.48 & 0.0003 \\
Risk ratio vs. control $(0 \% w / w$ ash $)$ & 0.78 & 0.88 & 1.59 & 3.99 & 1.34 & 5.19 \\
\hline
\end{tabular}

\section{DISCUSSION}

\subsection{Volcanic ash and resource location}

Many pollinating insects rely during foraging activities on visual and chemical information (Raguso and Willis 2005). Flower attributes such as color distribution, morphology, and volatile emissions can trigger innate and/or learnt responses during process of food location (Chittka and Thomson 2001). Receiving partial or altered information could imply a decreased foraging performance, or the onset of learning processes that could eventually lead to successful floral identification (Raguso and Willis 2005). Based on our field study, in which flowers were covered with a simulated ash rain, we conclude that despite having a strong spatial memory (Menzel et al. 2005), honeybees cease to visit flowers covered with volcanic ash during a short period. This behavioral shift is attributed to the changes in the visual information received by the honeybee caused by coverage of the color patterns by volcanic particles, as shown by the overall reflectance change within the visual range of the honeybee. The increase in reflectivity registered in ashcovered flowers, with maximum differences found at $\sim 400$ and $\sim 570 \mathrm{~nm}$, suggests visual information changes within the spectral sensitivity of the honeybee (with sensitivity peaks at 350, 440, and $540 \mathrm{~nm}$, Menzel and Blakers 1976). The strong predisposition of honeybees to single species visits (floral constancy) (Waser
1986) added to the mismatch of visual information, could explain this abrupt shift in behavior. Changes in flower volatile profile due to ash presence could be an additional factor influencing location, but volatile profiling is necessary in order to assert this. An increase in visits was observed after a 24-h period, probably responding to the plastic behavior of honeybees (Hammer and Menzel 1995), period after which individuals learn the "new" color of flowers, associating it with the presence of food.

\subsection{Feeding on ash-contaminated resources}

Given the high level of exposure to volatile ash of anthers and nectaries in many flower species, organisms that forage under an ash-fall scenario, could consequently feed on contaminated resources. Our results showed that contaminated pollen, nectar, and water were consumed in equal amounts as uncontaminated ones. Regardless of the ash-contamination level in the resource, consumption was no different for uncontaminated pollen, sugar solution, or water, suggesting the absence of an innate or learnt deterrent response towards this type of contamination. It's important to note that bees were kept under experimental conditions that differed from the natural situation (for example: absence of foraging and in-hive activities). Nevertheless, feeding habits and energy demands of tested bees was comparable to those observed in free-living preforaging individuals since the observed amount of ingested 
sugar $(10 \mathrm{mg} /$ day $)$ contained in the $1.8 \mathrm{M}$ solution was similar to that of free-living individuals (9-34 mg/day) (Rortais et al. 2005).

The observed indiscriminate consumption behavior between contaminated and clean resources means that no behavioral restriction would prevent honeybees from collecting contaminated food and water. Although honeybees can regulate the income of resources into the hive (Martínez and Farina 2007; Ramírez et al. 2010), this is mostly restricted to quality (i.e., sugar concentration). This, added to the fact that the ingestion of ashcontaminated water and sugar solution negatively impacted survival, would not only mean a detrimental effect to foragers, but transfer of resources through trophalaxis to preforaging individuals could affect in-hive adults and larvae. Although this study did not establish the mechanisms through which insect survival is affected, Wille and Fuentes (1975) and Edwards and Schwartz (1981) observed that laceration and ash accumulation in the digestive tract would disrupt normal functioning and cause death causes by the high concentration of volcanic glass. Nectivorous insects could be especially susceptible to ingesting ash-contaminated resources since most insects that feed on liquid resources (blood, nectar, or sap) have long, narrow, and convoluted guts without the kind of protective mechanisms against abrasion that could be found in insects feeding on solid foods (for example, leaf-feeding caterpillars) (Gullan and Cranston 2005). The detrimental effect could not only be restricted to specific periods of ash fall, but in social insects that store resources, contamination could have extended negative effects through the reserves (i.e. stored honey and pollen).

\subsection{Additional factors affecting survival}

The extent to which ashes would affect insect pollinating ecology would strongly depend on the magnitude of the volcanic event (i.e., surface affected, duration, amount of emitted material, periodicity), time of the year and proximity to the volcano. In the case of the Chilean volcanic complex Puyehue-Cordon Caulle, the strongest portion of the activity was during austral winter, when pollinating activity was at its minimum. As ambient temperatures started to rise, the volcanic activity decreased, and the observed negative effect on honeybee populations where minimal (Huerta, personal observation). Although in regions where windborne ash coincided with higher temperatures, loss of foragers was observed (Bravo, personal observation), probably due to a combination of factors established in this study, but no direct evidence exists of this. Situations of extreme volcanic eruptions that affect large areas for long periods [for example, the 1183 Krakatau eruption, one of the largest in recorded history (Robock, 2000)] could be strong forces in shaping communities (Foster et al. 1998). In other less intense scenarios where eruptions occur in biotic active periods (i.e., spring/summer) or in tropical regions where pollination regimes are longer, the impacts could be more severe disrupting pollinating activity at a regional scale with knock on effects such as local extinctions (Masciocchi 2012) and unpredictable consequences on community assemblies. Although this work shows a strong detrimental effect on honeybee survival, some species might remain unaffected or even benefit from volcanic events, such as the Chilicola spp. bee that uses dead branches to nest in. Wille and Fuentes (1975) reported an increase in their population numbers after the 1963-1965 eruptions of the Irazú volcano in Costa Rica. Factors affecting population numbers were thought to be an increase of dead trees utilized as nesting places, in addition to the fact that the anthers and nectaries of flowers pollinated by this species were morphologically protected from falling ash.

\subsection{The effects on apiculture}

The negative effects to apiculture due to volcanic activity could be important if volcanic activity and/or wind-mobilized ash coincides with periods of foraging activity. The increased mortality risk observed in this study could 
probably translate in reduced honey production due to a decline in honeybee colony size. Any transfer of ashes to stored nectar and pollen could impact directly honey taste and quality and ultimately human health. Studies are ongoing (Martinez et al.) in order to establish such consequences. Under volcanic ash fall conditions, it would be important for bee keepers to prevent honeybees from foraging contaminated sources. Transporting colonies to more favorable areas could be a way of mitigating the consequences, but wherever this is not an alternative, sealing hive entrances and providing supplementary nutrition to affected colonies could diminish the risk of increased mortality.

\section{CONCLUSIONS}

Volcanic eruptions can be detrimental to some species, while others can tolerate the effects and even benefit from the disturbance. In the particular case of the honeybee, volcanic ash could impact survival and in consequence honey production and agricultural activities that depend on this species pollinating services. The underlying mechanisms through which volcanic ash can cause reduced insect fitness could be diverse and range from behavioral alterations to direct physical effects caused by ash-contaminated resources. Impact on individual plant and insect species and their knock on effects in pollination webs would strongly depend on plant traits such as the degree of exposure of nectar and pollen-bearing structures to direct ash contact. Likewise, insect traits such as the degree of specialization (i.e., specialist vs. generalist pollinators), digestive tract characteristics (some tracts could be less convoluted and more resistant to abrasion than others), and sociality could strongly influence the impact.

\section{ACKNOWLEDGMENTS}

This study was financed through the Programa Científico-Tecnológico de apoyo a la emergencia de la erupción del volcán Puyehue (PROEVO). We would also like to thank Ana Julia Pereira for helping with field studies and two anonymous referees that reviewed the manuscript.
Cendres dans l'atmosphère: les effets des émissions de cendres volcaniques sur la relation plante-pollinisateur et leur conséquence possible sur l'apiculture

Apis mellifera/abeille/pollinisateur/cendre volcanique/ perturbation/complexe volcanique de Puyehue-Cordon Caulle

Asche in der Luft: Auswirkungen vulkanischer Ascheemissionen auf Pflanzen-Bestäuber-Beziehungen und mögliche Konsequenzen für die Bienenhaltung

Apis mellifera/Störung/Bestäuber/vulkanische Asche/ Vulkankomplex Puyehue-Cordon Caulle

\section{REFERENCES}

Chittka, L., Thomson, J.D. (2001) Cognitive Ecology of Pollination. Cambridge University Press, Cambridge

Edwards, J., Schwartz, L. (1981) Mount St. Helens ash: a natural insecticide. Can. J. Zool. 59, 714-715

Foster, D.R., Knight, D.H., Franklin, J.F. (1998) Landscape patterns and legacies resulting from large, infrequent forest disturbances. Ecosystems 1, 497-510

Gullan, P.J., Cranston, P.S. (2005) The Insects. An Outline Of Entomology. Blackwell, Malden

Hammer, M., Menzel, R. (1995) Learning and memory in the honeybee. J. Neurosci. 15, 1617-1630

Hegland, S.J., Nielsen, A., Lázaro, A., Bjerknes, A.-L., Totland, Ø. (2009) How does climate warming affect plant-pollinator interactions? Ecol. Lett. 12, 184-195

Hrassnigg, N., Crailsheim, K. (1998) The influence of brood on the pollen consumption of worker bees. J. Insect Physiol. 44,393-404

Klein, M., Bernard, E.V., James, H.C., Steffan-Dewenter, I., Cunningham, S.A., Kremen, C., Tscharntke, T. (2007) Importance of pollinators in changing landscapes for world crops. Proc. R. Soc. B Biol. Sci. 274, 303-313

Kleinbaum, D.G., Klein, M. (2006) Survival analysis: a self-learning text. Biometrics 62, 590

Klostermeyer, E. C., Corpus, L. D., Campbell, C.L. (1981) Population changes in arthropods in wheat following volcanic ash fall-out. Melanderia 37, 45-49

Martínez, A.S., Farina, W.M. (2007) Honeybees modify gustatory responsiveness after receiving nectar from foragers within the hive. Behav. Ecol. Sociobiol. 62, 529-535

Masciocchi, M., Pereira, A.J., Lantschner, M.V., Corley, J.C. (2012) Of volcanoes and insects: the impact of the Puyehue-Cordon Caulle ash-fall on populations of invasive social wasps, Vespula spp. Ecol. Res. (in press) 
Menzel, R., Blakers, M.. (1976) Comparative Colour Receptors in the Bee Eye-Morphology and Spectral Sensitivity. J. Comp. Physiol. A 108, 11-33

Menzel, R., Greggers, U., Smith, A., Berger, S., Brandt, R., Brunke, S., Bundrock, G., Hülse, S., Plümpe, T., Schaupp, F., Schüttler, E., Stach, S., Stindt, J., Stollhoff, N.,Watzl, S. (2005) Honey bees navigate according to a map-like spatial memory. Proc. Nat. Acad. Sci. USA 102, 3040-3045

Ne'eman, G., Jürgens, A., Newstrom-Lloyd, L., Potts, SG., Dafni, A. (2010) A framework for comparing pollinator performance: effectiveness and efficiency. Biol. Rev. Cambridge Philos. Soc. 85, 435-51

Ollerton, J., Winfree, R., Tarrant, S. (2011) How many flowering plants are pollinated by animals? (Hederson, D.R.(ed.). Oikos 120, 321-326

Potts, S.G., Vulliamy, B., Dafni, A., Ne'eman, G., O'Toole, C., Roberts, S., Willmer, P. (2003) Response of plant-pollinator communities to fire: changes in diversity, abundance and floral reward structure. Oikos 101, 103-112

Raguso, R., Willis, M. (2005) Synergy between visual and olfactory cues in nectar feeding by wild hawkmoths, Manduca sexta. Anim. Behav.69, 407-418

Ramírez, G.P., Martínez, A.S., Fernández, V.M., Corti Bielsa, G., Farina, W.M. (2010) The influence of gustatory and olfactory experiences on responsiveness to reward in the honeybee. PloS one 5, e13498

Robock, A. (2000) Volcanic eruptions and climate. Rev. Geophys. 38, 191-219
Rortais, A.R., Arnold, G.A., Halm, M.-P., TouffetBriens, F. (2005) Modes of honeybees exposure to systemic insecticides: estimated amounts of contaminated pollen and nectar consumed by different categories of bees. Apidologie 36, 71-83

Shoji, S., Nanzyo, M., Dahlgren, R. (1993) Volcanic Ash Soils: Genesis, Properties and Utilization. Elsevier, London

Simkin, T. (1993) Terrestrial volcanism in space and time. Annu. Rev. Earth Planet.Sci. 21, 427-452

Small, C., Naumann, T. (2001) The global distribution of human population and recent volcanism. Glob. Environ. Chang. Part B: Environ. Hazards 3, 93-109

Traveset, A., Richardson, D.M. (2006) Biological invasions as disruptors of plant reproductive mutualisms. Trends Ecol.\& Evol. 21, 208-216

Waser, N.M. (1986) Flower constancy: definition, cause, and measurement. Am. Nat. 127, 593-603

Wille, A. \& Fuentes, G. (1975) Efecto de la ceniza del Volcán: Irazú (Costa Rica) en algunos insectos. Rev. Biol. Trop 3, 165-175

Wilson, T.M., Cole, J.W., Stewart, C., Cronin, S.J. \& Johnston, D.M. (2010) Ash storms: impacts of windremobilised volcanic ash on rural communities and agriculture following the 1991 Hudson eruption, southern Patagonia, Chile. Bull. Volcanol.73, 223-239

Woyke, J., Gabka, J. (2011) Effect of volcanic ash cloud over Poland on flight activity of honey bees. J. Apic. Sci. 55, 5-17 